\title{
The Modernization of the Russian Marxist Concept of the Nation in the Social Sciences and Humanities in the USSR in the Second Half of the Twentieth Century
}

\author{
Vyacheslav Vilkov \\ Ph.D. (Philosophy), Associate Professor, Taras Shevchenko National University of Kyiv \\ (Kyiv, Ukraine) \\ E-mail: tvvvilkof59@gmail.com \\ https://orcid.org/0000-0002-3542-0756
}

\section{Sergii Rudenko}

Doctor of Philosophical Sciences, Professor, Taras Shevchenko National University of Kyiv (Kyiv, Ukraine)

E-mail: rudenkosrg@gmail.com

https://orcid.org/0000-0001-9069-0989

\begin{abstract}
The paper analyses the processes of modernization of the "Marxist-Leninist historical and economic" interpretation of the concept of the "nation" in social and human sciences in the USSR in the second half of the $20^{\text {th }}$ century. In the paper, from the standpoint of modern scientism, on the basis of the principle of historicism, methods of systematic, comparative, discursive and content analysis, semantic innovations, determinants and leading trends of improvement of the concept of the national community were studied. The concept, which was not only the ideological core of the Marxist-Leninist "historical and economic theory of the nation", but an important conceptual element in the whole complex of social and political sciences in the USSR, had its own dominating social communist ideology with its world-historical process narrative.

The material of the article is of particular importance for adequate understanding of the history of the development of socio-philosophical and political sciences in the USSR and Ukraine in the second half of the 1960s, the first half of the 1990s, as well as for the scientific understanding of the dominant analytical and ideological prescripts of Soviet Marxism in its ideological confrontation with the Western political science, and for understanding of the theoretical foundations of nation-building and nationstate building during the years of Soviet power.

Keywords: socio-political studies, USSR, Stalin, the Stalin's definition of the nation, "Russian Marxist Theory of the Nation", Marxist-Leninist historical and economic theory of the nation, AustroMarxism, Scientific communism, Communist metanarrative, concept of the "nation", concept of the "Soviet people"
\end{abstract}

(C) Vilkov, Vyacheslav, 2019

(C) Rudenko, Sergii, 2019 
Received: March 1, 2019; accepted: March 30, 2019

Ukrainian Policymaker, Volume 4, 2019: 69-84.

https://doi.org/10.29202/up/4/10

\section{Introduction}

In the second half of the $20^{\text {th }}$ century, in the Soviet scientific and educational literature (adapted versions of their reproductions) for the system of higher and specialized secondary education, social scientists and, first of all, the representatives of the scientific community of philosophers and political researchers, classified the Marxist conception of the nation as "historical and economic". They proved that this conception, unlike all theoretical models that were created by the Western scientists, is considered to be scientific and true to life, expresses and upholds democratic values.

In the publications of Russian and Ukrainian authors attitudes changed. It happened in the post-Soviet period. Being "historical and economic", the Marxist interpretation was considered as one the of several main paradigms (approaches, theoretical models, conceptions) in the system of modern theoretical knowledge of nations and nationalism, which retains scientific influence and has a practical value, but in the world of science (outside the post-Soviet intellectual space) it does not have a competitive advantage over the political, psychological, cultural and ethnic theories of the nation, developed by the Western researchers during the second half of the $20^{\text {th }}$, beginning of the $21^{\text {st }}$ centuries.

\section{Literature review and problem statements}

It should be especially mentioned that some Ukrainian leading experts in the field of studying the history of theoretical ideas about the nation in the publications of the late 1990s, referring to the statements done by their Western colleagues, began to popularize the opinion that the independent "Marxist-Leninist historical and economic theory of the nation" had not been created. For example, George Kasyanov said, "According to many modern researchers (B. Anderson, T. Bottomor, R. Debre, Oras B. Devis, N. Pulantsas, and others), "traditional" or orthodox Marxism did not have its own theory of the nation at all" [Kasyanov, 1999: 49].

Another authoritative Ukrainian scientist Alexey Kartunov, in his publication for the general reader (in textbooks), relying on the statements of the Western researchers (Walker Connor, Alfred Low, Charles Herod) and the assessments of some Ukrainian specialists in the history of theories of the nation, and by accusing Stalin of direct borrowing of the key ideas in interpreting the essence of the national community from the works of Karl Kautsky (and, ostensibly without mentioning their authorship), called this German social democrat the developer of the "historical and economic (i.e. Marxist - Authors) theory of the nation" [Kartunov, 2007: 65-66; Kartunov, 1999: 138-139].

According to our estimates, among the representatives of the Western scientific community, the most famous and radical about the "scientific status" of the Marxist conception of the nation was the world-famous leader in the research direction of the "theory of nations and nationalism", the English scientist Antony Smith, "Neither Marx nor Engels, Lenin nor Stalin, Luxemburg nor Kautsky, endeavoured to present a theory or model of nations and nationalism 
per se, not only because these phenomena were viewed with suspicion, if not outright hostility, even by those who conceded their political significance, but because the "science" with which they were concerned was intimately linked to a specific worldview and political strategy that sought to reduce all phenomena, at the explanatory level at least, to their economic basis, deriving cultural and political identities and movements from the class alignments thrown up by a specific stage in the development of the mode of production. It was in this context that the "formalism" associated with Marxist analysis became prominent: the idea that nations provided the forms and vessels, while class formations and their ideologies provided the content and ends to which the next stage of history aspired. This type of reductive reasoning has left a strong imprint on some latterday approaches to the study of nationalism, even where the theorists no longer accept the worldview and strategy in which it was embedded, and even when they eschew the cruder forms of economic reductionism and ideological formalism found in some of Marx's followers" [Smith, 1988: 12].

\section{Research results}

The Smith's highly negative assessments of the theoretical status of the Marxist interpretation of national genesis and the nature of nations will be left on his scientific conscience or civility ${ }^{1}$. If we turn to the estimates of the alternative committed and ideological camp (to Marxists themselves), than it should be admitted that the Soviet Marxist-Leninist name of the theory "Historical and Economic Theory of the Nation" is fully justified, since the axiomatics of the Marxist materialist understanding of history is ideologically and conceptually localized and its objective logic (common lows) of the development through the change of social and economic formations and the world-wide historical role of the driving forces of social transformations is conceptually reflected ("the subjects of the historical process", such as classes, peoples and nations). However, in the Soviet scientific discourse the name "Historical and Economic Theory of the Nation" was not historically original or politically and ideologically authentic. Since it was Joseph Stalin (in his work "Marxism and the National Question" (1913), on the basis of the fundamental criticism of the ideas of the Austro-Marxists Otto Bauer and Karl Renner, introduced the basic postulates of the Marxist concept of the nation and proposed such a definition, that the Soviet social scientists throughout the post-Stalin era, even in the wake of the anti-Stalinist moods in the 1950s and early 1960s, could not substantially "supplement" or "modernize") who, in 1929, gave it a clear name "Russian Marxist Theory of the Nation."

${ }^{1}$ Despite the dominance of the scientism principles in the studies of Western specialists, primarily those from England and America, in the field of social and humanitarian theories and, specifically, in the treatment of the "theories of the nation and nationalism", it is difficult to judge the adequacy of their results in relation to the Marxist theory of the nation, as well as the essence and specificity of its various editions. It is especially difficult to do it on the question of comparing the concepts of Russian Marxism and Austro-Marxism. One of the main problems lies not only in the ideological preferences, likings and dislikings of Western scholars, but in the fact that if the "text of 1913" by Joseph Stalin (i.e., "Marxism and the National Question") "was published along" with its "later works" ("London, 1936") and had "great international significance", "not only among the Communists", but "especially in the dependent (third or colonial. - Authors) world", and as the British Marxist historian Eric Hobsbaum noted [Hobsbaum, 1992: 2], "for the first time since the date of its first publication ninety years ago "the shameful fact" was finally eliminated" [Anderson 2002: 9-10]. Namely, since the publication of the Austro-Marxist Otto Bauer's "National Question and Social Democracy" (1907 original, the Russian translation was offered in 1909), on the basis of which Stalin offered his definition of the nation). Only in 1996 the first chapter from its independent publication (in 1924) appeared in the English translation in the collection of articles "Mapping the Nation" of the London Verso publishing house. 
Moreover, he categorically added, "There is only one option left, to recognize that the Russian Marxist theory of the nation is the only correct one" [Stalin, 1952: 335].

The public introduction by Joseph Stalin of the term "Russian Marxist" can be explained by the fact that, perhaps, he was the first, among Russian social democrats, to develop a clear conception of the nation, which he contrasted with another influential trend in European social democracy - Austrian Marxism, which had its own theory of the nation and a popular, in the early 20th century among many ideologues of national movements and left-wing parties, project of "cultural-national autonomy". Moreover, in 1929 there was no one to oppose to the head of the USSR and the CPSU (b), even in terms of terminology. Therefore, only a "faithful continuator of the Lenin's work" could afford to abandon his categorical political and ideological attitude, which he formulated in the appeal "To the Jewish Workers" in 1905, "The Party (RSDLP. - Authors), to destroy any thought about its national character, gave itself the name not Russian, but Russia`s” [Lenin, 1979: 267].

The name of the theory, called "Russian," perhaps, was the only thing that the multinational and "internationalist" scientific community of the Soviet era social scientists did not discuss publicly and could not borrow it under the "Stalin brand". In the literature of the second half of the $20^{\text {th }}$ century, since the time of the "Khrushchev thaw", its mentioning was secretly tabooed. In numerous publications of that period on the "history of theories of the nation" (of a scientific and educational nature) the following stages were normally distinguished: "pre-Marxist ideas about nations"; "the scientific contribution of K. Marx and F. Engels to the development of its scientific, materialistic concept"; "the Leninist stage in the development of the nation's historical and economic theory" and "modern bourgeois theories", whose scientific value was always questioned in the USSR.

Undoubtedly, numerous and multifaceted publications of the classics of Marxism-Leninism (Marx, Engels and Lenin) allowed Soviet researchers to find additional arguments to recognize the priority of their ideas for scientific interpretation of national genesis and states, determine the essence of national entities and characteristics of their attributive traits and types, as well as assessing the role of nations in the political and cultural history of Europe and the world.

However, despite large numbers of works by the founders of Marxism and their followers (including the ideologist of the Second International, the leader of the German Social Democrats Karl Kautsky), in which the genesis and social nature of nations, the essence and historical limitations of national states and nationalism were considered in various aspects (historical, economic, political, cultural, social, ideological, psychological, etc.), none of them proposed a definition of the national community. Only in the polemical and partially commentary works of Vladimir Lenin, who avoided the "definition game", there are fragmentary statements about such basic, from the point of view of social and philosophical teaching and political doctrine of Marxism, signs of nations as "unity" of "economic relations", "territory" and "language". The leader and ideologue of the Russian social democrats sharply criticized theoretical ideas of the nation, national culture and statehood of Austro-Marxists Otto Bauer and Karl Renner ${ }^{2}$

\footnotetext{
${ }^{2}$ We will give a brief outline of them. Thus, the theorist and ideological leader of the Austrian Social Democrats, the philosopher Otto Bauer, who openly positioned himself a as a follower of the teaching and methodology of the knowledge of Karl Marx, in his fundamental work "The National Question and Social Democracy" (1907), proposed the following definition, "The nation is a community of people connected with the unity of character on the basis of a common fate" [Bauer, 1909: 139]. He explained it very tautologically, "The commonality of fate means the joint experience of the same fate on the basis of constant relations and interaction". Such a community of life "operates in two directions". The qualities assigned by the nation on the basis of the community of fate are transmitted through natural
} 
for "idealism", "psychologism" and "bourgeois nationalism", argued the political failure and danger of their project of "cultural-national autonomy" aimed at strengthening the international unity of the proletariat, the revolutionary social democratic movement, in order to destroy the national oppression in the bourgeois, albeit, formally legal, democratic and multinational state.

And yet, Joseph Stalin in his work "Marxism and the National Question", was the first, among the theorists and ideologists of Marxism (both European and Russian), to offer a logically clear formula for the concept of the nation, which was conceptually related to the axioms of this doctrine. In 1913, this formula was published in an article style in three issues of the "Enlightenment" journal, which was edited by Vladimir Lenin, and who was well acquainted with its ideas, spoke well of it and recommended to the Bolshevik party organizations in Russia for review.

In this work, Stalin intended, as he noted, "to resist militant nationalism", whose "wave" was "threatening to capture the working masses". Having analyzed in detail popular among European and Russian Social-Democrats ideas of the Austro-Marxists, and analytically "exhausted", as he writes, "all signs" of the national community ("unity of language", "unity of territory", "unity of economic life and economic cohesion" and "unity of mental make-up"), which most political thinkers and ideologists of the second half of the $19^{\text {th }}$, beginning of the $20^{\text {th }}$ century considered typical of nations, he finally stated, "A nation is a historically constituted, stable community of people, formed on the basis of a common language, territory, economic

heredity and through cultural inheritance, when "the cultural values created by the nation on the basis of the same community of fate are transmitted to another" [Bauer, 1909: 115-116, 25]. For such a national community the unity of the territory and culture, and even the language is not obligatory (that is what Kautsky was sharply criticized for). Otto Bauer's language was considered only a "tool" of culture, an "external regulator" of "social cooperation of individuals", unable to influence "cultural values" and, most importantly, "national character" [Bauer, 1909: 118-119, 132, 135-136]. From the socialist ideological position, the Austrian Marxist developed a political project of "cultural-national autonomy". Its essence was that by changing the "legal system" in a "multinational state" and transforming each of the national entities (as many representatives of any nationality living on the territory of the state) into a "legal entity" with the right of "taxation"; creating through "free statements of citizens" "National Cadastres"; conducting on their basis elections for autonomous and independent, in their decisions from central institutions, bodies of "cultural-national self-government", which would be entitled to solve all the arising questions (in fact only humanitarian) of the vital activity of every nation (for example, the language of school education and publishing, as well as functioning of communes and counties, etc.).

Another ideological leader of the Austrian socialists, the lawyer Karl Renner (also known as Rudolf Springer, Synopticus, since 1945 was the first president of Austria after the end of the Second World War), proposed a purely culturological definition. The nation, he stressed, "Is a union of likeminded and equally speaking people", it is nothing more than a "cultural community of a group of modern people not connected with a land". [Springer, 1909: 43-44] At the same time, in order to solve national problems in the contemporary bourgeois society, he declared it necessary to carry out not a political institutionalization of nations (an independent national state), but a political and legal project of "cultural-national autonomy". First of all, for the Austro-Hungarian Empire. The struggle for socialism of "different nations in Austria" he did not consider to be their primary task (declaring that it is relevant only for the "European" nations of "Germany, France and England"), or a way to solve the "national question". In his autonomist project, it was said that the initial principle or meaning of the "right of nationality" was, "Nationality must become one of the legal signs determining the state of a person", i.e. publicly declared by the individual "belonging to a nation" in legal terms should "be a part of the basic legal and public rights". Whereas each national community "should be constituted as a union of people on the basis of modern democracy, as an organization of legal defense" [Springer, 1909: 80-81, 111, 44, 257-259]. To find a detailed analysis of the theoretical and political ideas of Otto Bauer and Karl Renner on the national genesis, the nature of the national community, their typology, the draft resolution of the national question in multinational states, etc. [see, for example: Vilkov, 2014: 6-74]. 
life, and psychological make-up manifested in a common culture" [Stalin, 1951: 296]. It must be noted that this is a well-known part of the Stalin's definition. In addition, the author, debating with his ideological opponents of the time, and taking into account some possible prospects of an ideological struggle with anti-Marxists (for example, if in modern terms, adherents of constructivism, inventionalism or primordialism), emphasized that, "Any nation is not an accidental or ephemeral conglomerate, but a stable community of people"; "A nation is not a racial or tribal, but a historically formed community of people"; "The nation, like any historical phenomenon, is subject to the law of change, has its own history, a beginning and an end" [Stalin, 1951: 293, 297].

Another important theoretical postulation and doctrinal political idea of one of the ideologists of the RSDLP (b), which further influenced the national liberation processes in the Russian empire, especially lawmaking in the USSR and its initial legal regulations that determined the hierarchy in the multinational federal state (cultural-national, national-territorial or union republican status), was the statement that "none of the indicated characteristics is enough individually exhaustive to provide a definition of the nation. Moreover, the absence, of at least, one of these signs is enough for a nation to cease to be a nation." In general, the categorical Stalin's theoretical and political answer, "Only the presence of all the signs taken together gives us a nation" [Stalin, 1951: 297].

The Stalin's definition of the nation cited from the work of 1913, the formational framework of national communities and the interpretation of their basic features were almost undeniable dogma for the Soviet social scientists of the second half of the $20 \mathrm{~s}$ - second half of the $50 \mathrm{~s}$ of the $20^{\text {th }}$ century. The Soviet scientists of later ideological epochs $(1960 \mathrm{~s}-1980 \mathrm{~s})$ faced a difficult dilemma - to reject Stalin's concept of the nation or significantly modernize it, and thus create a new anti-Stalin or counter-Stalin version of the definition of the nation, and not to abandon the systemically important postulates of the Marxist-Leninist teaching and the prescripts of the official communist ideology (which together turned into metanarrative in the USSR) was impossible. Stalin logically built up his interpretation of the essence of the national community on the axioms of the Marxist theory of society, its structure and development. Therefore, the negation of one (concept) inevitably required the negation of another (the whole Marxist-Leninist theory).

However, after the change of the next "political and ideological epochs", some Ukrainian researchers who were influential in the Soviet period, for example, Froim Gorovskiy (in such a fundamental, collective and unique for the post-Soviet scientific community edition as the "Short Encyclopedia of the Ethnostatescience (Nationhood and Statehood)", 1996), already in the post-Soviet period began to declare that the "Stalin's definition of the nation is of a compromise nature, since it eclectically united historical, economic and psychological views on the nature of the phenomenon of the nation itself". In addition, Froim Gorovskiy emphasized, "With a careful analysis it is not difficult to notice that the first three signs of the nation are given by Stalin "the way Kautsky did it", while the fourth is taken from Bauer"

\footnotetext{
${ }^{3}$ In this case, we note that in the works of Karl Kautsky, who sharply criticized the theory of the nation and the project of cultural-national autonomy of Austro-Marxists Karl Renner and Otto Bauer (especially the latter, because he did not understand the essence of national culture, progressiveness in the capitalist era of such a form as a "national state" compared to a "state of nationalities", considered Jews to be "a nation that has no future" and therefore does not need cultural-national autonomy), defined attributive, for social and political philosophy of Marxism, features of the national community (especially the historicity of its nature, an unconditional necessity for the formation of the nation of "community of language" and "territory"), nevertheless, did not suggest a definition for it.
} 
[Gorovskiy, 1996: 139] A similar assessment, but with an additional emphasis on the fact that the Stalin's definition is a "plagiary", was offered by Alexey Kartunov in his textbooks [see The above data on the publications of 1997 and 2007]. George Kasyanov did the same but more tactfully by giving a reference in his monograph (1999) [Kasyanov, 1999: 46]. This way Stalin received a new accusation of non-Marxism. "It is not difficult to notice", he stressed, "that Stalin in some elements of his synthetic definition appears to be a real "Weberian", although being an orthodox Marxist, he introduced a very important element in it "the unity of economic life" (in this respect he appears to be not so much Marx, who had little interest in the issues of nations in general, but the German thinker Friedrich List, who was one of the founders of the economic theory of the nation)" [Kasyanov, 1999: 46]. In general, as a result of the analysis of the Russian-Soviet Marxist approach to the conceptual modelling of the nation's phenomenon, George Kasyanov stated, "If we turn to taxonomy, then it should not be called "Marxist-Leninist", but "Marxist-Stalinist" or, for example, "Marx-Stalin-KautskyRenner" (the list goes on)". Although he still admitted, "Some parts of it, if perceived not as a canon, but as a more educational means, seem to be quite correct and interesting for the researchers of the question of the nation, therefore you should not treat it as an "ideological trash", what some modern researchers suffer from" [Kasyanov, 1999: 49].

However, before turning to the analysis and evaluation of innovations in the interpretation of nature and signs of the national community, which were made by the Soviet social scientists in the discourse of Marxism-Leninism and the CPSU history narrative in the second half of the twentieth century, it is necessary to recall our own Stalin's clarifications of the definition of the nation.

Therefore, in this case, of particular importance is the fact that the USSR scientists, in their intellectual searches and generalizations, took into account, as a rule, the wording of the text "Marxism and the National Question" (1913). In addition, in fact, they did not take into account the very important ideas that were presented in the later Stalin's publication "The National Question and Leninism. The Answer to the Comrades Meshkov, Kovalchuk and Others" (1929), entered in the $11^{\text {th }}$ volume of his Collected Edition, published in1952.

In this publication, for analysing and evaluating the evolution of theoretical ideas about the nature of nations in Soviet Marxism of the second half of the $20^{\text {th }}$ century, two things seem fundamental. Firstly, Stalin himself corrected the meaning of the "fourth feature" of the national community ("psychological makeup, manifested in the unity of culture"), the interpretation of the name and the meaning, what caused great discussions among Soviet specialists during the 1960s - 1980s. Secondly, he categorically refused to recognize the state as the necessary "fifth" attribute/ characteristic of the nation (national community).

Thus, in the definition that he edited in 1929, "the father of nations and the leading light of all sciences" emphasized, "Russian Marxists have long had their own theory of the nation". According "to this theory, a nation is a historically formed stable community of people that emerged on the basis of the following four features, namely, on the basis of a common language, common territory, common economic life and common psychological makeup, manifested in the unity of specific features of the national culture." In other words, Stalin himself changed the meaning of his own initial interpretation of the "fourth attribute". Although he did not present it in details.

At the same time, concerning the ideas of "statism", which opponents of Stalinist Marxism persistently offered to us in order to supplement the concept of the nation; its creator rejected them in a reasonable way. Such an approach can be recognized not only as a claim for the 
infallibility of the "faithful continuer of Lenin's work" in the theory of the "national question", but also by striving to make the Marxist understanding of the nature of the national community more ambiguous and precise, and politically more instrumental. It allowed preventing all the unnecessary controversy in the future (even non-public) in the Soviet scientific community and political class.

So, Stalin, back in the late 1920s, on the proposal to improve "The Theory of the Nation of Russian Marxism" and "add one more attribute of the nation to the existing four", namely, "the existence of its own separate state", "without having which" "no nation can exist", replied, "I think that the proposed scheme with its new, fifth feature of the concept of the nation is absolutely erroneous and cannot be justified either theoretically or practically, or even politically" [Stalin, 1952: 334].

Explaining his disagreement with the need to "supplement" and "correct" the "Russian Marxist theory of the nation", he said that theoretically such a scheme "leads to absurd conclusions" and "cannot be considered scientific." The leader of the Soviet Union, and the chief ideological theoretician of the Communist Party (Bolsheviks) wrote, "With your scheme, we would have recognized only those nations that have their own, separate from others, state, and all the oppressed nations deprived of independent statehood, would have to be blot out of the category of nations. Furthermore, the struggle of the oppressed nations against national oppression and the struggle of colonial peoples against imperialism would have to be removed from the concept of "the national movement" and "national liberation movement"" [Stalin, 1952: 334]. He also stressed, "Moreover, under your scheme you would have to assert that Irish became a nation only after the formation of the Irish Free State, and until that time they were not a nation"; "Norwegians were not a nation until the separation of Norway from Switzerland, but became a nation only after this separation"; "Ukrainians were not a nation when Ukraine was a part of Russia, they became a nation only after the separation from Soviet Russia at the time of the Central Council and Hetman Skoropadsky, but they again ceased to be a nation after they united their Ukrainian Soviet Republic with other Soviet republics into the Union of Soviet Socialist Republics. A lot of similar examples could be cited" [Stalin, 1952: 334-335].

From a "practical and political" point of view, Stalin remarked that such a "scheme", firstly, "leads to the justification of national, imperialist oppression, the carriers of which resolutely do not recognize oppressed nations, nations that do not possess full rights and those nations that do not have their own individual states, and believe that this circumstance gives them the right to oppress these nations". Secondly, this "scheme leads to the justification of bourgeois nationalists in the Soviet republics", which "prove that the Soviet nations ceased to be nations after they went to unite their Soviet republics into the Union of Soviet Socialist Republics" [Stalin, 1952: 335].

In the anti-Stalin epoch, especially during the 1960s, and the early years of the 1970s (and not only because of counter-Stalinism), but again in the second half of the 1970s, the first half of the 1980s, in the Soviet scientific community with the participation of researchers from European socialist countries, an active discussion among the representatives of various humanitarian, social and political sciences (philosophy, history, scientific communism, law, sociology, ethnography, cultural studies, social psychology, anthropology, etc.), took place on the problems of conceptual understanding of the phenomenon of the nation. One of its main reasons was to strive for either de-Stalinization or scientific modernization of the "historical and economic theory of the nation" through a more precise definition of the characteristics of 
the national community. That, respectively, required the development and introduction of a new scientific discourse, adequate to the social and political realities and ideological trends of the time, new its definition.

An additional intellectual stimulus and ideological platform for Soviet social and political scientists in their debates on topical and key problems of national genesis, national statehood, national culture, the ideology of nationalism and, ultimately, the definition of the essence of the national community, was the accessibility of conceptual ideas about these phenomena of Western researchers (translated literature and reference books, as well as monographs, articles and dissertations devoted to the criticism of non-Marxist concepts, called "bourgeois", and on the whole spectrum of national questions).

Above all, in the second half of the $20^{\text {th }}$ century, the Soviet social scientists were engaged in the terminological correction of the Stalinist theoretical classification or designation of nations as "historically established stable communities of people". Most of them (each of these scientists maximally exploited the quotations of Karl Marx, Friedrich Engels and Vladimir Lenin) stated in their publications that all communities of people (including the nation) are, without a doubt, "historical" and took an active part in the updating of the general noumenon (historical), initiating the tendency of using of ideas of theoretical sociology and ethnology. At the same time, they often unnecessarily played with the meanings and senses of the newly introduced concepts.

In their works, many of the Soviet researchers and their colleagues from the socialist countries began to insist that the nation is a binary "social and ethnic organism" [Kulichenko, 1972: 58]. Or "a social organism with which and on the basis of which nationality was formed and strengthened as a complex of characteristic ethnic features, attributes and specific qualities" [Kozing, 1978: 173]. Some authors (usually historians, social philosophers) changed their accents and offered to interpret nations as a "historical phenomenon", but above all as "social" [Dashdamirov, 1976: 42], which has a clear timeframe of being and formational (capitalism/ socialism) features in the world history. A number of social scientists (mainly ethnographers, ethnopsychologists and philosophers) emphasized that national communities are a "historical social phenomenon" that "exists only in the ethnic form" [Kaltakhchan, 1978: 7]. Some of them, especially in the publications of the 1980s, proposed to consider national communities "in the contradictory duality of the social" (social-class) and "ethnic" [Iordan, 1980: 69], and recommended appropriate names for them: "ethnosocial" or "socio-ethnic" community. In the early 1980s, under the influence of the works of the high-status Soviet community ethnographers, the concept of "ethnosocial organism" was introduced into scientific circulation as one of the most common noumena for the national community [Bromley, 1983: 63].

In general, the main trend in the course of modernization/reform of the Soviet MarxistLeninist theory of the nation and its basic concept was that scientists began to treat "ethnic" not as the essence of a nation, but only as its "socio-historical uniqueness", or "universal historical form or method of organizing its content". And on the contrary, the social in a nation was recognized by them as its essence, substantiality, qualitative certainty which manifests itself in the ethnic form, but completely depends on the class nature of nations. It is the social and class essence of a nation, all social scientists and humanities tirelessly repeated, that influences its political institutionalization, the type of ideology, the society dominating values (nationalistic or internationalist) and the character of cultures (bourgeois, democratic or socialist).

In the work of the Academician of the Academy of Sciences of the GDR, Alfred Kozing, along with the joint opinion, in the context of the paradigm ideas of the Soviet Marxists about 
the relationship between the social and ethnic, the most generally understood as a "form of national community", as a "concrete form of its social content" or "social essence" and that a nation, as a historical form of the community of people differs mainly from other large and historical stable forms of communities (social groups) - ethnic groups, nationalities, classes, social strata, castes, ethno-confessional groups, etc., a rather non-standard social-politicalphilosophical idea for the Soviet Marxism-Leninism was expressed (published in the USSR in 1978). Actively quoting Vladimir Lenin, like all Marxists, he, but in his own way interpreted Lenin's axiom, "Nations are an inevitable product and an inevitable form of the bourgeois era of social development" [Lenin, 1977: 93)], and argued that they (nations) are not just a form of community (collectivity, or a large social group) of people of a certain, post-feudal period of history, but something more. He stressed, "In both socio-economic formations the capitalist and socialist, nations is first and foremost a natural form of the development of society" [Kozing, 1978: 120]. "A nation is a form of development of social existence that continues to exist even after the liquidation of capitalism and plays an important role in the historical development of society" [Kozing, 1978: 124].

On the assumption of such a general sociological message that equates "community" and "society", but without taking into account the fact that nations are not the only "social product" of social development processes even under capitalism, the German scientist made quite radical theoretical and political (because he did not take into account the institutional aspect of national reality, that is, the forms of state structure existing in the world and the nature of globalization processes) conclusions. He stated that a "bourgeois society naturally develops in a national form" [Kozing, 1978: 121], and a "socialist nation" is "a form of development of a socialist society" [Kozing, 1978: 125].

However, such a theoretical novelty remained almost unnoticed among Soviet social scientists and did not affect the process of modernization done by them of the historical and economic, Marxist-Leninist theory of the nation.

It should be especially mentioned that active discussions and innovations in the interpretation of the essence and dialectics of the interrelation of the phenomena and concepts of "ethnic", "ethnicity", "nationality", "national affiliation" and "national identity" in the human and social sciences in the USSR in the second half of the $20^{\text {th }}$ century were not only preconditioned by the internal factors of their development.

A major role was played by external challenges and requests. Firstly, the rivalry with Western researchers and their latest theoretical models of nation and nationalism, many of whom actively used the above-mentioned concepts in their theories. The most fundamental question was, precisely, the definition of the essence of "ethnic" and "social" and their correlation in the national and the nation. Moreover, their objective content, as well as subjective (national: consciousness, self-consciousness, identity, identification, psychology, feelings, etc.) manifestations, structure and functions were also important. Secondly, the problematics and themes of the relationship between "ethnic" and "social" turned out to be extremely relevant not only for the purpose of further updating the Marxist-Leninist, historical and economic concept of the nation, but also because of the need to develop theoretical foundations for the Communist Party ideological innovations stated in the early 1960s. And above all, the main idea of the new ideologem and mythologem, which were proclaimed in 1961 at the XXII Congress of the CPSU in the report by Nikita Khrushchev, was that from the representatives of different nationalities (nations, ethnic groups, etc.), a "new historical community of people the Soviet people", was formed in the Soviet Union. 
Over time, this "type of consolidation of the people" was interpreted in the literature by the Soviet scientists not only as historical, but also as a social and international community, which is characterized by: state-political and territorial unity (with a federal, union structure), common socialist economy, uniform in social peculiarities and diverse in national characteristics culture, strong socio-political and ideological (based on Marxist-Leninist ideology, communist ideals and goals, principles of internationalism, Soviet patriotism, the policy of strengthening the friendship of peoples done by the CPSU) inviolable unity of all classes, domains, nations and nationalities who, like a "family of the peoples of the USSR" under the influence of the socialist system and the Soviet political system, developed a common cultural way of expanding the sphere of the use of the language of international communication (Russian), values and features of the nation's psych.

For example, here is one of the standard definitions of the "Soviet people", which is given in a typical textbook (1981) on "Scientific communism", which, we remind, in the 1960s became a generally obligatory discipline in the system of higher education of the Soviet Union. "The Soviet people", stated the authors of the textbook, as well as the academicians and first figures in the formal and informal hierarchy of the Soviet community of social scientists and ideologists (Peter Fedoseyev, Viktor Afanasyev, Fedor Burlatskiy, Alexander Yakovlev, Vadim Zagladin, Suren Kaltakhchan and many others), "is a community of people that has one common homeland, common territory, one single economy that is based on social property, one single culture with socialist content and diverse in national characteristics, national languages and a language of international communication, common federative state and one common goal — building of communism.

The Soviet people represent a single collective of workers from cities and villages of the multinational USSR. The socialist social system gave rise to new psychology and a new spiritual image of the Soviet people. In their activities, they are guided by Marxist-Leninist ideology, the communist ideals of the working class, and the principles of proletarian and socialist internationalism.

In the formation of a new historical community of people - the Soviet people, the leading role was played by the CPSU..." [Scientific Communism, 1981: 320].

Of course, in terms of its content, the above definition of the Soviet people is, to some extent, similar to the Marxist-Leninist definition of the nation.

For this reason, in order to somehow operationalize the difference between the meanings and senses of these two concepts, in literature one significant theoretical clarification was given to its ideological pathos and stereotypes, "The Soviet people is not some kind of supernation that assimilates and replaces nations, but their international community"; its "social, ideological and political unity, integrity", which "functions as a complex international system, the structural elements of which are socialist nations and nationalities"; "the systemic organization of people of different nationalities". The Soviet people is a community of people "of a higher order than a nation". "The interaction of the national and the international occurs within" this "social and international community" and "is the source of the flourishing and rapprochement of the nations and nationalities of the USSR" [Scientific Communism, 1981: 321].

${ }^{4}$ In modern Western literature, the concept of the "civic nation" is used for this phenomenon, i.e. liberal and democratic interpretation of the political national community. It is conceptually defined as a solidary political and legal community of equal citizens of a democratic state (a republic where the principle of "sovereignty of the people" is guaranteed constitutionally), whose identity is not ethnic, but political. Its mental and ideological core is not ethnonationalism, but patriotism, as well as the principles and values of multiculturalism [read, for example: Vilkov, 2013: 317-322; Vilkov, 2018: 10-22]. 
It should be noted that a number of ideas of the GDR academician Alfred Kozing was identical with the narrative and logic of the new Soviet theoretical and communist ideological attitudes in interpreting the ratio of "ethnic", "national", "class" and "social" (primarily the division of nations into capitalist and socialist), as well as the formulation of strategic prescripts for a democratic national policy and state socialist building.

It should be emphasized that the narrative and logic of the new Soviet theoretical and communist ideological attitudes in interpreting the ratio of "ethnic", "ethnicity", "national" and "social", as well as the wording of strategic prescriptions for the democratic national policy and state socialist construction was identical with the ideas of the academician Alfred Kozing from the GDR. He, saying that he agrees "with the point of view" of "nationality being an ethnic characteristic of the nation", expressed by the philosopher Suren Kaltakhchan, who was considered to be one of the leading experts in the "nation theory" in the USSR, and revealing his understanding of the phenomenon and the concept of "nationality" ("national affiliation", "identity"), using the example of the German Alsatians and Lothingians, who became an integral part of the French nation, emphasized that it is, in one case, an "objective characteristic". Unless, of course, "we are talking about national identity in the sense of belonging to a nation as a complex social organism that includes ... of course ethnic identity" and "does not depend on how people determine their affiliation" (national, ethnic).

In the other case, "nationality affiliation/identity" is "only ethnicity belonging to one or another group of population with common ethnic features" [Kozing, 1978:164-165, 173]. And it is in this socio-historical dimension that "ethnic characteristic", ethnic similarity/ community and "national identity", firstly, "passes from the feudal nationality to the capitalist nation in the process of historical development" [Kozing, 1978: 172-173]. Secondly, it is then inherited from the feudal and bourgeois past by socialist nations. In general, the "nationality", as a combination of only ethnic features (including identity which is based on them), claimed the German academic, may be the same, but nations as objective historical communities (even with one ethnic/national identity) are often different. For example, "the German socialist nation in the GDR" and "the German capitalist nation in the FRG" [Kozing, 1978: 175-177].

Certainly, on the issue of the "correlation between ethnic and social-class in the national and the nation" and in numerous works by Soviet researchers, one can come up with theoretical approaches that are close to the above-mentioned one.

In particular, the Ukrainian researcher Alexander Kuts, reproducing the point of view on this issue of his colleague, says, "However, one cannot but agree with Yu. I. Rymarenko who writes that if there exist "two nations" in a bourgeois society in terms of social class, then in terms of ethnic there must be only one. No matter how acute the class struggle may be, it cannot destroy the "ethnic community." "However, as a necessary accent, which is ideologically Marxist and theoretically correct, he further states, "In other words, one should take into account the existence of the national community and not forget that it consists of certain classes. As long as the society is class-divided, all relations in it, including the national ones, have a certain class content and require "scientific objectivity and their fundamental assessment from the standpoint of the working class"" [Kuts, 1982: 13].

A famous Soviet philosopher Hermann Glezerman, having supported the theoretical tenets, supplemented them with a key Soviet Marxist philosophical, political and ideological assessment, saying that, "a nation has known ethnic elements, which means, it consists of people belonging to certain ethnic groups or tribes that, in the process of forming a nation, had merged and formed a single whole"; "When the nation of a bourgeois society becomes 
socialist, ethnic elements are preserved". He stressed that "ethnic" or "national", even though it is borrowed when a bourgeois nation is transformed into a socialist one, does not become dominant, "does not define" its "social appearance", culture, self-consciousness and psychology. Therefore, "on the basis of the new emerging (socialist. - Authors) mode of production", a "radical change in the social nature" of national communities takes place [Glezerman, 1975: 13-14].

It is worth reminding that following great discussions, the Soviet social scientists also agreed that the "four features" (social and ethnic) of the national community that are classical for Marxism (common territory, economic life, language and psychological makeup manifested in the common culture) are necessary and sufficient to determine the nation. In addition, some logical corrections of the features, proposed by many of them, were insignificant.

Even less scientifically significant and theoretically reasoned in the Soviet period of the $70 \mathrm{~s}$ and $80 \mathrm{~s}$ of the last century were the recommendations of the scientists to proofread the names of the main ("four") features of the nation. The first of them, ("common language" in its original version) was proposed to be interpreted as "common literary language", "homogeneity of language", "unity of written language". The second was offered to rename "the unity of the territory", "the integrity of the territory". The third basic feature of the nation, as well as the two previous ones, did not cause any particular objections on the part of the Soviet social scientists, but it was suggested to clarify its meaning like this: "commonality of economic relations" or "commonality of industrial economy."

The most heated theoretical debates among Soviet researchers arose on the issue of understanding the essence (including structural elements) and the name of the "fourth" Stalin's characteristic of the nation - "The unity of mental makeup", manifested in the cultural affinity. And the problem of the theoretical modernization of this feature was generated in the Soviet scientific community not only by the complexity of the social and philosophical understanding of the subjective, social, psychological and mental constituent of all the processes of national genesis, national liberation or unification movements and nationbuilding, but also by the disciplinary differentiation and underdevelopment of the categorical apparatus (tools) of the set of "science of the spirit".

As a result, by the early 1980s, from the set of ideological and conceptual innovations to replace the outdated Stalin's name "mental makeup", in the discourse and the logic of the ideas of the Marxist-Leninist theory of the nation, which was influenced by the work of such iconic figures in the Soviet system of human and social sciences as Edward Bagramov, Yuri Bromley, Ahmed Gadzhiev, Afrand Dashdamirov, Leocadia Drobizhieva, Suren Kaltakhchan, Michael Kulichenko, to designate "the spirit and soul of the nation" as the subject of cultures and politics the following categories became dominant in the Soviet scientific literature: "national character," "national psychology," "national consciousness" and "national selfconsciousness." 5

Of course, each of the Soviet researchers, depending on his sectoral or disciplinary membership, his own theoretical ideas and preferences, sought to modify the interpretation of the essence, structure, socio-political and cultural functions of the above-mentioned mental phenomena. Thus, one could correct the meanings and senses of the concepts traditional for the Soviet Marxist-Leninist theory of the nation. There were those who rejected all

\footnotetext{
${ }^{5}$ At the same time, we need to stress that the concept of "national identity", which is more characteristic of the conceptions (theoretical models) of the nation and nationalism of Western researchers, has hardly been used.
} 
sorts of innovations, even lexical ones, tried to prove the "non-scientific status" of such a "novelty". And some, contrary to the "collective voice", formed in the scientific community, unsuccessfully, but with the help of a complex, as a rule, "scientific-like" argument, tried to introduce into the scientific circulation their own non-standard ideas and concepts for the theoretical reflection of the spiritual side of the existence of nations.

On the other hand, the collective Soviet modernization of the Marxist-Leninist ("Russian Marxist") concept of the nation did not lead to borrowings from its ideological opponents, did not take steps to come closer to the paradigmatic theoretical models that were created by Western scientists in the second half of the $20^{\text {th }}$ century on the basis of axiomatics and methodologies of various social sciences. Certainly, they became known to the representatives of the Soviet Union scientific community, but were criticized by them because of their conviction or even because of the totality of the Communist Party "voluntarily-compulsory" control. Although, it was mostly done, not from theoretical, but from political and ideological standpoints. Above all, the Soviet Marxists rejected the innovative, heuristic ideas of those modern approaches and concepts whose authors developed the dichotomy of nationalism, national communities and identities as ethnic and political phenomena.

The definitions, that became classical by the mid-80s of the last century in the USSR, says a lot about the rejection of Western experts in the field of "theories of the nation and nationalism", as well as the modernization of the "Russian Marxist" (Marxist-Leninist) theory of the nation and its basic concept. Thus, in the high-status and exemplary for the Soviet times scientific publication - "Philosophical Encyclopedic Dictionary" (the article was written in 1983 by Suren Kaltakhchan), the nation was defined as "a historical community of people formed during the formation of the unity of their territory, economic ties, literary language, some features of their culture and character" [Philosophical Encyclopedic Dictionary, 1983: 417].

\section{Conclusions}

It should be noted that the Marxist-Leninist interpretation of the nation (historical and economic theory, theoretical model), the interpretation of its attributive system, is not popular among researchers of the post-Soviet countries. They are more focused on the concepts created by modern Western experts, within such a direction as "the theory of the nation and nationalism". Meanwhile, the regulatory framework, developed almost a hundred years ago on its ideas, political and ideological prescriptions, resulted in the forming of the state structure of the USSR and its sovereign republics (being constitutionally established by the states, it even provided membership in the creation of the UN for some of them). Furthermore, after the collapse of the USSR it served as a corner stone for establishing the current, recognized by the international community, boundaries. In some independent states of the former Soviet Union, the theory continues to influence (institutionally and ideologically) cultural and political processes of the reproduction and development of some ethnonational communities residing on their territory.

Finally, it is necessary to recognize that the numerous scientific disputes and the second half of the 1970s, the first half of the 1980s of the twentieth century, were practically ineffectual. A scientific breakthrough in the radical renewal of the Marxist-Leninist, historical and economic theory of the nation, respectively, the meanings and senses of its concept, did not happen. The representatives of the social sciences were reconciled by a research attitude similar to 
the one that was announced 1970 as a result of a broad discussion of the 1960s ("Voprosy Istorii" journal: 1966, No 4, 6, 12; 1967, No 6-7; and finally number 8, 1970). They came to the conclusion that, "a detailed discussion during the debates confirmed the opinion of the majority" of Soviet scientists, that "the definition of the nation that we have (similar to Stalin. - Authors) includes the main features of all types of nations"; it "is scientific, Marxist", "is a part of the Marxist-Leninist theory of the nation". And although such a definition "does not disclose the specific features of each" of the types of nations, however, "the accepted Marxist concept of the nation (with the exception of some clarifications) does not need to be reconsidered" [the cit. of: Gorovskiy, Rimarenko, 1985: 64-65].

In general, despite its duration and a large number of participants who represented different branches of sociopolitical and humanitarian knowledge in the USSR, the discussion did not bring any fundamentally new scientific, theoretical or political significant results. Stalin played a "cruel joke" with the adherents of Marxism-Leninism when an unsolvable problem and dilemma arose. Rejection of the meanings of the Stalinist definition of the nation would inevitably mean the abandonment of the basic tenets of the Marxist theory of society and its history. And vice versa, the recognition of the scientific truth of the axiomatics of the Marxist theory of the historical process logically and naturally required such a definition of the national community with its main features, which would make it possible to introduce nothing more than a stylistic correction of the Stalin's formula.

Thus, the entire, more than 30-year-old, a debate began and ended with only a slight clarification of the name and some meanings of the features of the national community and did not touch the essence of the Stalin's definition of the nation with its meanings and integrity.

\section{[D] References}

Bauer, Otto. The National Question and Social Democracy. St. Petersburg, 1909. (In Russian). Bromley, Yuri. Essays on the Theory of Ethnos. Moscow: Science, 1983. (In Russian).

Communism and Nations. Moscow: Nauka, 1985. (In Russian).

Dashdamirov, Afrand. Nation and personality. Baku: Elma, 1976. (In Russian).

Ethnonational Development of Ukraine. Terms, the Definition of Personality. Kiev: 1993. (In Ukrainian).

Glezerman, Hermann. Classes and nations. Moscow: Political Literature Publishing House, 1974. (In Russian).

Gorovskiy, Froim and Rimarenko Yuri. Marxist-Leninist Theory of the Nation and Socialist Practice. Kiev, Vyshcha shkola, 1985. (In Russian).

Gorovskiy, Froim. Stalin's definition of the nation. Short Encyclopedia of the Ethnostatescience (Nationhood and Statehood). Kiev: Dovira: Genesis, 1996. (In Ukrainian).

Gorovskiy, Froim, Alexe Kartunov, and U. Rimarenko. Nation. Short Encyclopedia of the Ethnostatescience (Nationhood and Statehood). Kiev: Dovira: Genesis, 1996. (In Ukrainian).

Hobsbawm, Eric. Nations and Nationalism since 1780. Programme, Myth, Reality. 1992 https://keimena11.files.wordpress.com/2014/01/hobsbawm_nations_and_nationalism_ since_1780.pdf.

Interethnic relations. Terms and Definitions: Dictionary. Kiev, 1991. (In Ukrainian).

Iordan, Michael. Nationalism versus Internationalism. Moscow: Nauka publishing house, 1980. (In Russian). 
Kaltakhchan, Suren. Introductory Wording. Kozing A. Nation in History and Modernity (A research held in connection with the historical-materialistic theory of the nation). Moscow: Progress publishing house, 1978. - (In Russian).

Kartunov, Alexey. The Western theories of Ethnicity, Nation and Nationalism: Educational Text-Book. Kyiv: University of Economics and Law, Krok, 2007. (In Ukrainian).

Kartunov, Alexey. Introduction to Ethnopolitical Science: Scientific-Educational Text-Book. Kyiv: Lybid, 1999. (In Ukrainian).

Kasyanov, George. Theories of nation and nationalism. Kyiv: Lybid, 1999. (In Ukrainian).

Kozing, Alfred. Nation in History and Modernity (A research held in connection with the historical-materialistic theory of the nation). Moscow: Progress publishing house, 1978. (In Russian).

Kulichenko, Michael. National Relations in the USSR and their Development Trends. Moscow: Mysl, 1972. (In Russian).

Kuts, Alexander. The Interrelation of Class and National Relations in a Developed Socialist Society. Kiev: Vyshcha shkola, 1982. (In Russian).

Lenin Vladimir. To the Jewish Workers // Complete Set of Works, Vol. 10, Moscow: Political Literature Publishing House, 1979. (In Russian).

Lenin, Vladimir. Karl Marx. Complete Set of Works, Vol. 26. Moscow: Political Literature Publishing House, 1977. (In Russian).

Nations and Nationalism. B. Anderson, O. Bauer, M. Hroch etc. Moscow: Praxis. (In Russian). Scientific Communism: A Textbook for Higher Educational Establishments. P.N. Fedoseiev, V.G. Afanasiev, K.N. Brutenets and others. Vol. 5. Moscow: Politizdat, 1981. (In Russian).

Smith, Antony. Nationalism and Modernism 2003 http://milliyyet.info/wp-content/ uploads/2015/11/Anthony-D.-Smith-Nationalism-and-Modernism.pdf

Stalin, Joseph. Marxism and the National Question I. V. Stalin. Writings Vol. 2. Moscow. State Political Literature Publishing House, 1951. (In Russian).

Stalin, Joseph. National Poll and Leninism. Answer to the Comrades Meshkov, Kovalchuk and others. I.V. Stalin. Writings. Vol. 11. Moscow. State Political Literature Publishing House, 1952. (In Russian)

Philosophical Encyclopedic Dictionary. Moscow: Sov. Encyclopedia. (In Russian).

Springer, Rudolph. National Problems: The Struggle of Nationalities in Austria. St. Petersburg, 1909. (In Russian).

Vilkov, Vyacheslav. Genesis of the Concept of the Nation. Third Publication. Kiev: Published by Karpenko V.M., 2014. (In Russian).

Vilkov, Vyacheslav. The Ideologeme and Mythologeme of the National Idea: Ukrainian Political and Philosophical Tradition in the Discourse of Modern Theory of Democracy (part two). Współpraca Europejska, Warszawa, Polska, Wydawca - Consilium Sp. z o.o., 2018, Vol. 5 (36). (In Ukrainian).

Vilkov, Vyacheslav. Western Nationology of $20^{\text {th }}$ Century: Conceptual Portraits. History of Nation and Nationalism Theories. Saarbrücken: Lambert Academic Publishing, 2014. (In Russian). 